\title{
DAYA TERIMA DAN KANDUNGAN GIZI KUE BOLU CUKKE SUBTITUSI TEPUNG UBI JALAR UNGU
}

\author{
Manjilala $^{1}$, Sirajuddin ${ }^{1}$ \\ ${ }^{1}$ Jurusan Gizi, Politeknik Kesehatan Kemenkes, Makassar \\ Korespondesni : Manjilala@poltekkes-mks.ac.id
}

\begin{abstract}
Bolu cukke is one of the traditional cake Bugis-Makassar, commonly consumed by the community, especially when enjoying a break. In order for a benefit value of Bolu Cukke, it takes effort to enrich the nutritional content, one of which is to replace wheat flour with sweet potato flour. A pre-experiment research conducted in Food Technology Laboratory of Nutrition Poltekkes Kemenkes Makassar, with number of panelist amoung 50 people. Nutritional content was analyzed using Kjhedal method for protein, gravimetric for fat and titrimetric for carbohydrate. Analyzed by using Kruskal-Wallis and Mann-Whitney test with 95\% confidence level. The results showed that the acceptability based on the taste aspect in the four groups was the same ( $p=$ $0.275)$ the sample group was $75 \%$ preferred by the panelists. There were color differences in the four sample groups $(p=0,000)$, when compared with the substituted sample with purple sweet potato flour, the sample group was $50 \%$ preferably panelists. There were differences in the flavour in the four sample groups $(p=0.013)$, the sample group $50 \%$ preferred by the panelists. Acceptance based on taste aspect in all four groups was the same $(p=0.733)$, the sample group was $75 \%$ preferred by panelists. The highest protein nutrient content in the 0\% sample group, $75 \%$ group fat and $75 \%$ carbohydrate. This research suggests that Bolu Cukke substitution of purple sweet potato flour is very feasible to be used as an alternative of Complementary Feeding in pregnant mother and toddler.
\end{abstract}

Keywords: Acceptance, Nutrition Content, Bolu Cukke, Sweet Potato Flour

\section{LATAR BELAKANG}

Sebagai bahan pangan, produk olahan ubi jalar masih terbatas dalam bentuk makanan tradisional, seperti ubi rebus, ubi goreng, kolak, getuk, timus, dan kripik, yang citranya dianggap lebih rendah dibanding produk olahan asal terigu, beras atau ketan. Tingkat konsumsi ubi jalar relatif rendah, bahkan cenderung menurun. Sebagai bahan baku industri, produk olahan ubi jalar juga terbatas sebagai bahan campuran saos (BPS 2009).

Upaya peningkatan konsumsi ubi jalar melalui beragam produk yang menarik, bergizi, dan memberi nilai tambah dengan pengolahan yang sederhana diharapkan dapat diadopsi dan dikembangkan oleh industri skala rumah tangga.

Peningkatan konsumsi ubi jalar juga dapat dilakukan melalui promosi ubi jalar sebagai pangan fungsional dan pangan sehat. Senyawa betakaroten dan antosianin pada ubi jalar ungu yang bermanfaat bagi kesehatan perlu ditonjolkan untuk menghapus citra ubi jalar yang dianggap sebagai makanan inferior.

Salah satu cara yang dapat dilakukan dalam pemanfaatan ubi jalar ungu ialah dengan membuat tepung dan 
menjadikan bagian dari proses pembuatan makanan selingan. Salah satunya ialah dengan mensubtitusi tepung ubi jalar ke dalam proses pembuatan Bolu cukke.

Bolu cukke merupakan salah satu kue tradisonal Suku Bugis-Makassar yang umum dikonsumsi oleh masyarakat khususnya saat menikmati waktu istirahat. Bahan utama dari bolu cukke ialah tepung terigu, gula merah dan telur ayam, dengan bentuk kue yang kering serta padat, kue ini sangat cocok dikonsumsi oleh balita dan ibu hamil.

Agar bolu cukke memiliki nilai manfaat bagi balita dan ibu hamil, maka dibutuhkan upaya untuk memperkaya kandungan kue tersebut, salah satunya ialah mengganti tepung terigu dengan tepung ubi jalar.

Oleh karena itu pengembangan Bolu cukke Ubi Ungu sebagai alternatif PMT lokal bagi balita dan ibu hamil patut diapresiasi dan diuji coba agar balita dan ibu hamil dapat memperoleh manfaat dari produk tersebut.

Penelitian ini bertujuan untuk mengetahui daya terima dan kandungan gizi bolu cukke subtitusi tepung ubi jalar ungu

\section{Metode Penelitian}

Penelitian ini merupakan penelitian pra-eksperimen dengan menggunakan desain post test group design. Penelitian akan dilaksanakan di Laboratorium Teknologi Pangan Jurusan Gizi Poltekkes Kemenkes Makassar dan Laboratorium Politeknik Negeri Makassar pada tahun 2017. Panelis ialah mahasiswa dan dosen Jurusan Gizi Poltekkes Kemenkes Makassar sebanyak 50 orang.

Penelitian ini diawali dengan pembuatan tepung ubi jalar dilanjutkan dengan pembuatan bolu cukke, penilaian oleh panelis, analisis kandungan gizi, pengolahan dan analisis data dan terakhir penyusunan laporan penelitian.

Analisis kandungan protein menggunakan metode Kjeldahl. Analisis kandungan lemak menggunakan metode gravimetrik. Analisis kandungan karbohidrat menggunakan metode Titrimetrik.

Data daya terima dianalisis dengan menggunakan distribusi frekuensi. Tingkat perbedaan Daya terima dianalisis dengan menggunakan uji Kruskal-Wallis dan Mann-Whitney.

\section{HASIL PENELITIAN}

Daya Terima

Hasil uji daya terima berdasarkan aspek warna, aroma, tekstur dan rasa dapat dilihat pada tabel 1 . 
Tabel 1

Daya Terima Bolu Cukke Subtitusi Tepung Ubi Jalar

\begin{tabular}{|c|c|c|c|c|c|c|c|c|}
\hline \multirow{2}{*}{ Konsentrasi Sampel } & \multicolumn{2}{|c|}{ Warna } & \multicolumn{2}{|c|}{ Aroma } & \multicolumn{2}{|c|}{ Tekstur } & \multicolumn{2}{|c|}{ Rasa } \\
\hline & $\mathrm{n}$ & $\%$ & $\mathrm{n}$ & $\%$ & $\mathrm{n}$ & $\%$ & $\mathrm{n}$ & $\%$ \\
\hline \multicolumn{9}{|l|}{ Tepung Ubi Jalar 0\% } \\
\hline Tidak Suka & 3 & 6,0 & 13 & 26,0 & 12 & 24,0 & 10 & 20,0 \\
\hline Suka & 47 & 94,0 & 37 & 74,0 & 38 & 76,0 & 40 & 80,0 \\
\hline \multicolumn{9}{|l|}{ Tepung Ubi Jalar 50\% } \\
\hline Tidak Suka & 11 & 22,0 & 6 & 12,0 & 13 & 26,0 & 9 & 18,0 \\
\hline Suka & 39 & 78,0 & 44 & 88,0 & 37 & 74,0 & 41 & 82,0 \\
\hline \multicolumn{9}{|l|}{ Tepung Ubi Jalar 75\% } \\
\hline Tidak Suka & 19 & 38,0 & 11 & 22,0 & 12 & 24,0 & 6 & 12,0 \\
\hline Suka & 31 & 62,0 & 39 & 78,0 & 38 & 76,0 & 44 & 88,0 \\
\hline \multicolumn{9}{|l|}{ Tepung Ubi Jalar $100 \%$} \\
\hline Tidak Suka & 20 & 40,0 & 20 & 40,0 & 12 & 24,0 & 6 & 12,0 \\
\hline Suka & 30 & 60,0 & 30 & 60,0 & 38 & 76,0 & 44 & 88,0 \\
\hline$p^{l)}$ & \multicolumn{2}{|c|}{0,000} & \multicolumn{2}{|c|}{0,013} & \multicolumn{2}{|c|}{0,733} & \multicolumn{2}{|c|}{0,275} \\
\hline
\end{tabular}

${ }^{1)}$ Uji Kruskal-Wallis; $\alpha=0.05$

Tabel 1 menunjukkan bahwa sebagian besar panelis memberi respon suka pada keempat kelompok sampel, yaitu masing-masing 94,0\% pada konsentrasi $0 \%, 78,0 \%$ pada konsentrasi $50 \%, 62,0 \%$ pada konsentrasi $75 \%$ serta $60,0 \%$ pada konsentrasi $100 \%$.

Berdasarkan analisis statistik menunjukkan bahwa terdapat perbedaan warna pada keempat kelompok sampel tersebut $(p=0,000)$.

Berdasarkan nilai Mean Rank kelompok subtitusi tepung ubi jalar ungu (50\%, 75\% dan 100\%) maka kelompok subtitusi $50 \%$ memiliki warna yang lebih disukai oleh panelis.

Penilaian panelis berdasarkan aspek aroma menunjukkan bahwa sebagian besar panelis memberi respon suka pada keempat kelompok sampel, tertinggi terdapat pada kelompok sampel subtitusi $50 \%$ dan terendah pada kelompok $100 \%$.

Hasil analisis statistik menunjukkan bahwa terdapat perbedaan aroma pada keempat kelompok sampel tersebut $(p=0,013)$. Berdasarkan nilai Mean Rank kelompok sampel subtitusi $50 \%$ lebih disukai oleh panelis berdasarkan aspek aroma.

Penilaian panelis berdasarkan aspek tekstur menunjukkan bahwa sebagian besar panelis memberi respon suka pada keempat kelompok sampel, tertinggi terdapat pada kelompok sampel subtitusi $0 \%, 75 \%$ dan $100 \%$, terendah pada kelompok $50 \%$.

Hasil analisis statistik dengan menunjukkan bahwa tidak terdapat perbedaan tekstur pada keempat kelompok sampel tersebut $(p=0,733)$. Berdasarkan nilai Mean Rank kelompok sampel subtitusi $75 \%$ lebih disukai oleh panelis berdasarkan aspek tekstur.

Penilaian panelis berdasarkan aspek rasa menunjukkan bahwa sebagian besar panelis memberi respon suka pada keempat kelompok sampel, tertinggi terdapat pada kelompok sampel subtitusi $75 \%$ dan $100 \%$, terendah pada kelompok $0 \%$. 
Hasil analisis statistik menunjukkan bahwa tidak terdapat perbedaan rasa pada keempat kelompok sampel tersebut $(p=0,275)$. Berdasarkan nilai Mean Rank kelompok sampel subtitusi $75 \%$ lebih disukai oleh panelis berdasarkan aspek rasa.

Kandungan Gizi

Analisis kandungan gizi dilakukan di Balai Besar Laboratorium
Kesehatan Makassar. Zat gizi yang dianalisis ialah Protein, Lemak dan Karbohidrat. Analisis kandungan protein menggunakan metode Kjehdal, lemak menggunakan metode Gravimetrik dan Karbohidrat menggunakan metode Titrimetrik.

Hasil analisis kandungan gizi bolu cukke subtitusi tepung ubi jalar ungu ialah sebagai berikut :

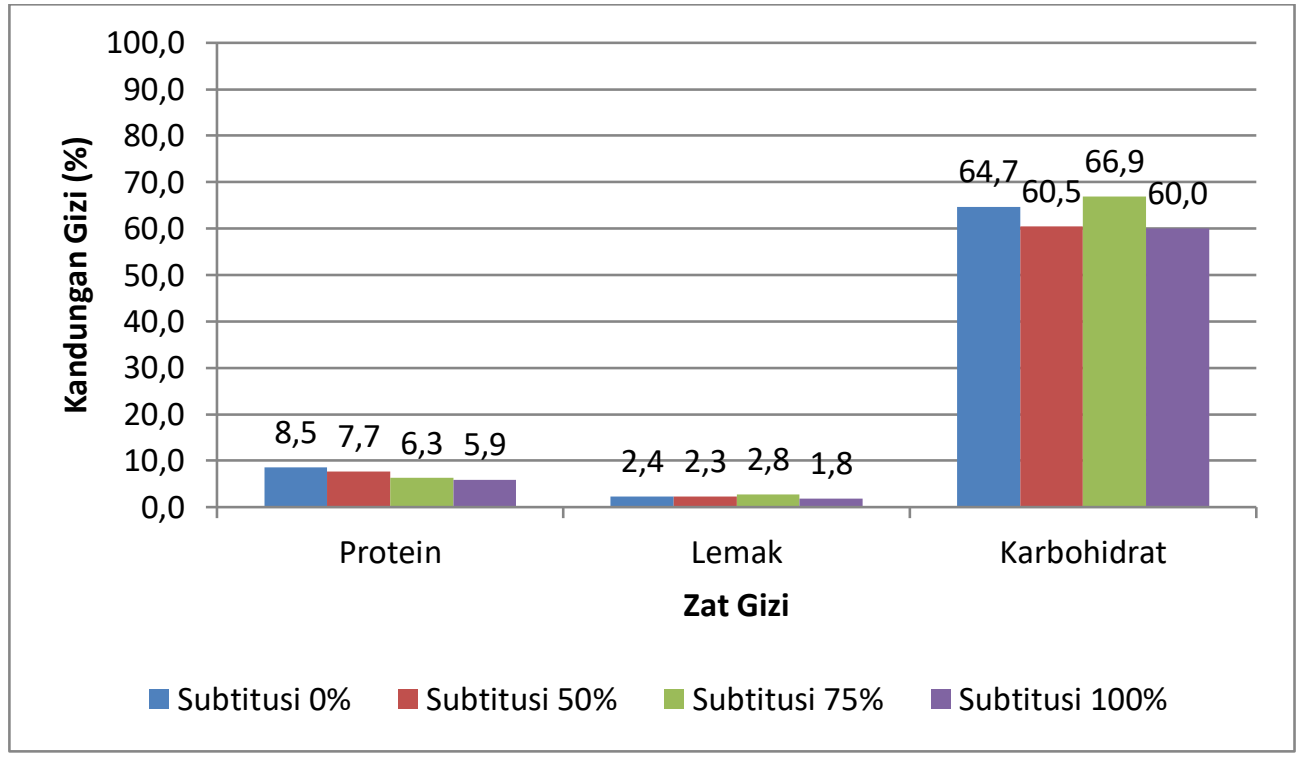

Gambar 1. Hasil Analaisis Kandungan Gizi Bolu Cukke Subtitusi Tepung Ubi Jalar Ungu

Gambar 1 menunjukkan bahwa kandungan protein tertinggi terdapat pada kelompok sampel subtitusi tepung ubi jalar ungu $0 \%$, terendah pada subtitusi $100 \%$. Sedangkan kandungan lemak tertinggi pada kelompok sampel subtitusi tepung ubi jalar ungu $75 \%$ dan terendah pada subtitusi $100 \%$. Kandungan karbohidrat, tertinggi pada kelompok sampel subtitusi tepung ubi jalar ungu $75 \%$ dan terendah pada subtitusi $100 \%$.

\section{PEMBAHASAN}

Bolu cukke dikenal sebagai salah satu kue tradisional suku bugis yang banyak dijumpai di Kabupaten Soppeng, Wajo, Pinrang, Sidrap dan sekitarnya. Bahan utama pembuatan bolu cukke ialah tepung terigu, gula aren dan telur ayam. Ketiga bahan tersebut diolah dan dipanggang dengan menggunakan alat khusus.

Tepung terigu yang terdapat pada bolu cukke sebenarnya bisa disubtitusi atau bahkan digantikan dengan jenis tepung yang lain, salah satunya ialah menggunakan tepung ubi jalar ungu. Subtitusi atau penggantian tepung terigu bertujuan agar masyarakat tidak tergantung ke tepung terigu yang $100 \%$ bahan utamanya harus didatangkan dari luar Negeri, disamping itu terigu mengandung gluten yang dapat menyebabkan gangguan kekebalan tubuh.

Menurut Ginting et al. 2008, tepung ubijalar ungu dapat mensubstitusi 50\% tepung ketan pada pembuatan jenang dan 
$15 \%$ bahan es krim komersial pada pembuatan es krim Tepung ubijalar juga merupakan bahan campuran yang baik untuk makanan balita pendamping ASI, baik dengan serealia maupun kacangkacangan.

Hasil uji daya terima yang kami lakukan terhadap Kue Bolu cukke subtitusi tepung ubi jalar ungu dengan melibatkan 50 panelis menunjukkan bahwa berdasarkan aspek warna, subtitusi tepung ubi jalar $0 \%$ lebih disukai oleh panelis, akan tetapi jika dibandingan antara subtitusi tepung ubi jalar 50\%, 75\% dan 100\%, maka yang paling banyak disukai warnanya ialah subtitusi 50\%. Berdasarkan aspek aroma, panelis juga lebih suka subtitusi tepung ubi jalar 50\%.

Penilaian panelis berdasarkan aspek tekstur dan rasa menunjukkan bawah tekstur dan rasa keempat kelompok relatif sama, meskipun demikian, tekstur dan rasa pada kelompok subtitusi tepung ubi jalar 75\% lebih disukai oleh panelis.

Hasil penelitian Anton Ramadhan Ketra dan Okta Wulandra (2015) tentang subtitusi tepung ubi jalar dalam pembuatan bolu gulung, menunjukkan bahwa paneli lebih menyukai warna, tesktur dan rasa bolu gulung dengan subtitusi $50 \%$ tepung ubi jalar ungu.

Kandungan gizi merupakan salah satu parameter penting dalam penentuan kualitas bahan makanan, jika bahan makanan tersebut akan direkomendasikan sebagai makanan tamabahan untuk balita dan ibu hamil maka pengujian kandungan gizi sangat penting dilakukan.

Berdasarkan petunjuk Teknis Pemberian Makanan Tambahan (PMT) pada Balita dan Ibu Hamil tahun 2017, kandungan gizi PMT pada balita minimal memiliki energi sebesar 160 Kalori, 3,2-4,8 gram protein, 4-7,2 gram lemak. Sedangkan pada ibu hamil, energi minimum 270 Kalori, minimum 6 gram protein, minimum 12 gram lemak.

Hasil analisis kandungan gizi bolu cukke subtitusi ibu jalar ungu, menunjukkan bahwa kandungan protein paling rendah sebesar 5,9 gram/100 berat bahan, lemak ialah 1,8 gram/100 gram bahan dan karbohidrat 60 gram/100 gram bahan.

Jika dihubungkan dengan hasil uji daya terima, dimana kelompok sampel subtitusi ubi jalar ungu 50\% dan 75\% lebih disukai oleh panelis maka berdasarkan kandungan gizi, kedua kelompok sampel tersebut cukup layak dijadikan sebagai alternatif PMT bagi ibu hamil dan balita jika dilihat dari kandungan protein yaitu sebesar 7,7 gram/100 gram pada kelompok sampel $50 \%$ dan 6,3 gram/100 gram pada kelompok $75 \%$. Akan tetapi kandungan lemaknya masih perlu ditingkatkan.

\section{KESIMPULAN}

1. Daya terima berdasarkan aspek rasa pada keempat kelompok relatif sama ( $\mathrm{p}=0,275)$ akan tetapi berdasarkan Mean Ranks, kelompok sampel 75\% lebih disukai oleh panelis.

2. Terdapat perbedaan warna pada keempat kelompok sampel $(\mathrm{p}=0,000)$, kelompok sampel 0\% lebih disukai oleh panelis, akan tetapi jika dibandingkan dengan sampel yang disubtitusi dengan tepung ibu jalar ungu, kelompok sampel $50 \%$ lebih disukai panelis.

3. Terdapat perbedaan waroma pada keempat kelompok sampel $(\mathrm{p}=0,013)$, kelompok sampel $50 \%$ lebih disukai oleh panelis.

4. Daya terima berdasarkan aspek rasa pada keempat kelompok relatif sama $(\mathrm{p}=0,733)$ akan tetapi berdasarkan Mean Ranks, kelompok sampel $75 \%$ lebih disukai oleh panelis.

5. Kandungan gizi protein tertingi pada kelompok sampel 0\%, lemak kelompok $75 \%$ dan karbohidrat $75 \%$.

\section{SARAN}

Kue bolu cukke subtitusi tepung ubi jalar ungu sangat layak dijadikan sebagai alternatif PMT pada ibu hamil dan balita, hanya saja perlu dilakukan upaya untuk meningkankan kandungan lemak pada kue tersebut sehingga semua persyaratan 
minimal PMT yang telah ditentukan oleh Kementerian Kesehatan RI dapat tercapai.

\section{DAFTAR PUSTAKA}

Antarlina, S.S. dan M. Jusuf. 2001. Pengolahan tepung ubijalar beberapa varietas pada umur panen yang berbeda. Prosiding Seminar Nasional Inovasi Alat dan Mesin Pertanian untuk Agribisnis. Badan Litbang Pertanian-Perteta. Jakarta. p. 227-235

El Husna, N., Novita, M., \& Rohaya, S. (2013). Kandungan Antosianin dan Aktivitas Antioksidan Ubi Jalar Ungu Segar dan Produk Olahannya. AGRITECH, 33(3), 296-302

Kusumawardani, L.S. 2008. Pengaruh pengolahan tepung terhadap sifat fisikkimia serta retensi $\beta$-karoten pada ubijalar oranye dan antosianin pada ubijalar ungu. Skripsi S1. Jurusan Teknologi Hasil Pertanian, Fakultas Teknologi Pertanian Universitas Brawijaya. Malang

Suda, I., T. Oki, M. Masuda, M. Kobayashi, Y. Nishiba, and S. Furuta. 2003. Physiological functionality of purplefleshed sweet potatoes containing anthocyanins and their utilization in foods. JARQ 37(3):167-173

Utomo, J.S., E. Ginting, dan S.S. Antarlina. 1999. Teknologi pengolahan ubijalar dan ubikayu mendukung diversifikasi pangan. Makalah Balitkabi No. 9977, disampaikan pada Gelar Teknologi Pengolahan Pangan Lokal di Surabaya, 9 Nopember 1999. Kanwil Deptan Propinsi Jawa Timur. $22 \mathrm{p}$. 